\title{
Pengarusutamaan Sustainable Development Goals (SDGS) Program Pengentasan Kemiskinan di Kota Pagar Alam
}

\author{
Sustainable Development Goals (SDGs) Mainstreaming on Poverty \\ Alleviation Program in Pagar Alam City
}

\section{Ricky Rahmatullah 1,2 , Teguh Endaryanto 3 , M. Irfan Affandi³}

\begin{abstract}
Abstrak: Kemiskinan merupakan salah satu tolok ukur dalam menilai keberhasilan atas usahausaha pembangunan yang berkelanjutan. Penelitian ini bertujuan untuk mengetahui hubungan anggaran program pengentasan kemiskinan oleh Pemerintah dan Pemerintah Kota Pagar Alam dengan persentase tingkat kemiskinan serta menentukan program prioritas pengentasan kemiskinan yang dapat ditempuh oleh Pemerintah Kota Pagar Alam terkait dengan pengarusutamaan pencapaian target $S D G$ s tahun 2030. Metode analisis dalam penelitian ini menggunakan Korelasi Pearson dan Analytical Hierarchy Process (AHP). Hasil penelitian menunjukkan, anggaran program pengentasan kemiskinan memiliki pola hubungan signifikan dengan penurunan persentase tingkat kemiskinan pada penganggaran yang kolaboratif dan sinergis melalui APBD Kota Pagar Alam dikombinasikan dengan APBN. Berdasarkan penilaian prioritas dalam model $A H P$, Program Pelayanan dan Rehabilitasi Kesejahteraan Sosial menjadi peringkat pertama atau pilihan utama Pemerintah Kota Pagar Alam dalam kerangka pengentasan kemiskinan dengan pengarusutamaan $S D G S$.
\end{abstract}

Kata Kunci: SDGs, Kemiskinan, Anggaran, Prioritas, AHP.

\begin{abstract}
Poverty is one of the indicators in judging the succeded sustainable development efforts. This study aims to analyze correlation between poverty alleviation budget programs by the Government and Local Government of Pagar Alam City with the percentage of poverty levels and determine poverty alleviation priority programs can be pursued by the Local Government of Pagar Alam City related to the achievement of SDGs mainstreaming target on 2030. The analytical method in this study uses the Pearson Correlation and Analytical Hierarchy Process (AHP). The results showed that the poverty allevation program budget had a signifiant corelation to the poverty percentage reduction in collaborative and synergistic budgeting through the APBD of Pagar Alam with APBN. Based on the assessment in the AHP model, the Social Welfare Services and Rehabilitation Program is first ranked or the first choice in the framework of poverty alleviation by SDGs mainstreaming.
\end{abstract}

Keywords: SDGs, Poverty, Budget, Priority, AHP.

\section{PENDAHULUAN}

Pengarusutamaan Sustainable Development Goals (SDGs) dapat dimaknai dengan membiasakan 17 tujuan dalam $S D G s$ sebagai tolak ukur baru yang berlaku tidak hanya di

\footnotetext{
${ }^{1}$ Magister Perencanaan Wilayah dan Kota, Program Pascasarjana Universitas Lampung,

${ }^{2}$ Bappeda Kota Pagar Alam, Pagar Alam

3 Jurusan Agribisnis Fakultas Pertanian, Universitas Lampung
} 
Indonesia tetapi juga berlaku pada tatanan masyarakat dunia. Dengan kata lain, pengarusutamaan $S D G S$ harus menggeser paradigma pembangunan yang selama ini dilaksanakan (bussines as usua). Adapun yang menjadi target pertama dalam SDGs ini adalah tanpa kemiskinan (no peverty), dimana kemiskinan menjadi suatu persoalan mendasar yang menjadi pusat perhatian pemerintah di negara manapun, sebab kemiskinan mempunyai dimensi dan tantangan yang luas baik di tingkat lokal, nasional maupun global. Alisjahbana dan Endah (2018) menerangkan bahwa goal 1 tanpa kemiskinan adalah tujuan akhir dari semua goals di dalam $S D G$ s, namun juga menjadi prasyarat agar pembangunan berkelanjutan dapat dilaksanakan dengan baik.

Pengentasan penduduk miskin menjadi salah satu prioritas pembangunan yang ada di Indonesia termasuk juga di pemerintah daerah, baik di tingkat provinsi maupun kabupaten dan kota. Sejalan dengan Peraturan Presiden Nomor 15 Tahun 2010 tentang Percepatan Penanggulangan Kemiskinan, serta diberlakukannya Undang-undang Nomor 23 Tahun 2014 tentang Pemerintahan Daerah dimana pelaksanaan otonomi daerah yang telah dimulai sejak tahun 2001, menuntut adanya upaya-upaya yang terstruktur, sistematis dan masif untuk mengatasi permasalahan kemiskinan dan peningkatan kualitas pelayanan kepada masyarakat miskin di seluruh penjuru Indonesia. Kemiskinan yang dihadapi akan banyak ditangani, diputuskan, dan dilaksanakan secara cepat dan efektif oleh pemerintah daerah, tanpa harus menunggu dan banyak bergantung pada instruksi dari pemerintah pusat. Adanya kewenangan daerah yang semakin besar ini, maka pemerintah daerah bersama pemangku kepentingan lainnya memiliki tanggung jawab dan keleluasaan yang lebih besar pula untuk mengambil keputusan-keputusan penting dan strategis terkait upaya penanganan masalah kemiskinan. INFID (2016) menyebutkan keberhasilan SDGs tidak dapat dilepaskan dari peranan penting pemerintah daerah, karena pemerintah kota dan kabupaten: (a) berada lebih dekat dengan warganya; (b) memiliki wewenang dan dana; (c) dapat melakukan berbagai inovasi; serta (d) ujung tombak penyedia layanan publik dan berbagai kebijakan serta program pemerintah.

Kota Pagar Alam Provinsi Sumatera Selatan yang menjadi lokasi penelitian dipilih secara sengaja dengan pertimbangan Pemerintah Kota Pagar Alam belum memiliki rumusan program prioritas berkaitan dengan pencapaian target $S D G s$ tanpa kemiskinan. Pada tahun anggaran 2018 Kota Pagar Alam merupakan daerah yang memiliki rasio dana perimbangan terhadap total pendapatan terbesar diantara seluruh daerah di Indonesia. Hal ini mengindikasikan bahwa kemampuan fiskal Pemerintah Kota Pagar Alam sangat bergantung pada sumber pembiayaan eksternal khususnya dari transfer Pemerintah Pusat. Persentase penduduk miskin di Kota Pagar Alam dilihat dari posisi relatif tahun terakhir merupakan yang terendah dibandingkan dengan kabupaten/kota lainnya di Provinsi Sumatera Selatan. Oleh karena itu, untuk mencapai target $S D G$ s tanpa kemiskinan yang terkesan sulit untuk dicapai, menjadi optimis untuk direalisasikan. Adapun penelitian ini terlebih dahulu menganalisis dan mencari tahu pola hubungan program pengentasan kemiskinan yang selama ini dilakukan (bussines as usual) yang dicerminkan melalui realisasi anggaran pemerintah, dengan persentase tingkat kemiskinan. Selanjutnya, dari program tersebut akan disusun urutan prioritas program pengentasan kemiskinan apa yang dapat ditempuh Pemerintah Kota Pagar Alam terkait dengan pencapaian target $S D G S$ tahun 2030. Hal ini bermanfaat untuk perencanaan pembangunan di daerah sebagai pengambilan langkah konkret dan mendasar berpikir global, bertindak lokal dalam menghapuskan kemiskinan. 


\section{METODE}

\section{Pembangunan berkelanjutan, target dan indikator SDGs tanpa kemiskinan}

Menurut Amin dan Musiyam (2017) Pembangunan berkelanjutan merupakan prinsip pengorganisasian untuk memenuhi tujuan pembangunan penduduk sekaligus mempertahankan kemampuan sistem alam untuk menyediakan sumber daya alam dan ekosistem dimana ekonomi dan masyarakat bergantung. Mahi (2017) menjelaskan dalam pembangunan berkelanjutan terkandung dua gagasan penting. Pertama, gagasan kebutuhan, khususnya kebutuhan esensial kaum miskin sedunia yang harus diberi prioritas utama. Kedua, gagasan keterbatasan, yang bersumber pada kondisi teknologi dan organisasi sosial terhadap kemampuan lingkungan untuk memenuhi kebutuhan kini dan hari depan.

Alisjahbana dan Endah (2018) menjelaskan, target untuk mencapai goal 1 SDGs mengakhiri kemiskinan dalam segala bentuk dimanapun, ukuran kemiskinan tidak hanya didasarkan pada kemiskinan berdasarkan dimensi pendapatan, namun juga pengukuran kemiskinan berdasarkan juga pada akses terhadap layanan dasar serta akses sumber daya produktif lainnya. Beragam ukuran kemiskinan tersebut dijabarkan dalam beberapa indikator seperti tingkat kemiskinan ekstrim, persentase penduduk di bawah garis kemiskinan, proporsi penduduk yang mendapatkan jaminan kesehatan, pendidikan dan perlindungan sosial.

Tabel 1. Target dan Indikator Sasaran SDGs Tanpa Kemiskinan

\section{Target no poverty \\ 1. Pada tahun 2030, mengentaskan kemiskinan ekstrim bagi semua orang yang saat ini berpendapatan kurang dari 1,25 dolar Amerika per hari; \\ 2. Pada tahun 2030, mengurangi setidaknya setengah proporsi laki- laki, perempuan dan anak-anak dari semua usia, yang hidup dalam kemiskinan di semua dimensi, sesuai dengan definisi nasional.}

3. Menerapkan secara nasional sistem dan upaya perlindungan sosial yang tepat bagi semua, termasuk kelompok yang paling miskin, dan pada tahun 2030 mencapai cakupan substansial bagi kelompok miskin dan rentan.

4. Pada tahun 2030, menjamin bahwa semua laki-laki dan perempuan, khususnya masyarakat miskin dan rentan, memiliki hak yang sama terhadap sumber daya ekonomi, serta akses terhadap pelayanan dasar, kepemilikan dan kontrol atas tanah dan bentuk kepemilikan lain, warisan, sumber daya alam, teknologi baru, dan jasa keuangan yang tepat, termasuk keuangan mikro.

Target Implementasi

1. Menjamin mobilisasi yang signifikan terkait sumber daya dari berbagai sumber, termasuk melalui kerjasama pembangunan yang lebih baik, untuk menyediakan sarana yang memadai dan terjangkau bagi negara berkembang, khususnya negara kurang berkembang untuk melaksanakan program dan kebijakan mengakhiri kemiskinan di semua dimensi;

2. Membuat kerangka kebijakan yang kuat di tingkat nasional, regional dan internasional, berdasarkan strategi pembangunan yang memihak pada kelompok miskin dan peka terhadap isu gender untuk mendukung investasi yang cepat dalam tindakan pemberantasan kemiskinan. Indikator sasaran

1. Proporsi sumber daya yang dialokasikan oleh pemerintah secara langsung untuk program pemberantasan kemiskinan;

2. Pengeluaran untuk layanan pokok (pendidikan, kesehatan dan perlindungan sosial) sebagai persentase dari total belanja pemerintah;

3. Proporsi pengeluaran rutin dan pembangunan pada sektor-sektor yang memberi manfaat pada kelompok perempuan, kelompok miskin dan rentan. 


\begin{tabular}{lll}
\hline Target no poverty & Target Implementasi & Indikator sasaran \\
\hline 5. Pada tahun 2030, membangun & \\
ketahanan masyarakat miskin dan & \\
mereka yang berada dalam kondisi & \\
rentan, dan mengurangi kerentanan & \\
mereka terhadap kejadian ekstrim & \\
terkait iklim dan guncangan ekonomi, & \\
sosial, lingkungan, dan bencana. & \\
\hline
\end{tabular}

Sumber: Bappenas (2017), Ringkasan Metadata Indikator Tujuan Pembangunan Berkelanjutan (TPB) / Sustainable Development Goals (SDGs) Indonesia.

\section{Analisis Korelasi Pearson}

Korelasi pearson atau sering disebut Korelasi Product Moment (KPM) merupakan alat uji statistik yang digunakan untuk menguji hipotesis asosiatif (uji hubungan) dua variabel bila datanya berskala interval atau ratio (Martono, 2010). Menurut Asra (2014) korelasi adalah kaitan atau hubungan antara dua variabel, yang bisa merefleksikan kaitan atau hubungan antara dua konsep yang ada didalam suatu teori. Korelasi pada dasarnya merupakan nilai yang menunjukkan tentang adanya hubungan antara dua variabel atau lebih serta besarnya hubungan tersebut, ini berarti bahwa korelasi tidak menunjukan hubungan sebab akibat. Hubungan antara dua variabel dapat karena hanya kebetulan saja dan dapat pula memang merupakan hubungan yang sebab akibat. Dua variabel berkorelasi apabila perubahan yang lain secara teratur, dengan arah yang sama atau arah yang berlawanan.

KPM disimbolkan dengan $r$ (rho) dengan nilai korelasi diantara $-1 \leq \mathrm{r} \leq 1$. Bila nilai $r=0$, berarti tidak ada korelasi atau tidak ada hubungan antara variabel. Sedangkan nilai $r=$ +1 diartikan terdapat hubungan positif dan apabila nilai $r=-1$ berarti terdapat hubungan yang negatif. Jika sekumpulan data $\mathrm{X}$ dan $\mathrm{Y}$ berpopulasi $\mathrm{N}$, koefisien korelasi dapat dihitung dengan rumus:

$r_{x y}=\frac{N\left(\sum X Y\right)-\left(\sum X\right)\left(\sum Y\right)}{\sqrt{\left(N \cdot \sum X^{2}-\left[\sum X\right]^{2}\right)\left(N \cdot \sum Y^{2}-\left[\sum Y\right]^{2}\right)}}$

Untuk memberikan tafsiran nilai $r$ atau mengukur kekuatan hubungan antar variabel ditunjukkan melalui tabel nilai korelasi. Tabel 2 menunjukkan nilai korelasi beserta makna nilai tersebut.

Tabel 2. Makna Nilai Korelasi Product Moment

\begin{tabular}{cl}
\hline Nilai & \multicolumn{1}{c}{ Makna } \\
\hline $0,00-0,19$ & Sangat rendah/sangat lemah \\
$0,20-0,39$ & Rendah/lemah \\
$0,40-0,59$ & Sedang \\
$0,60-0,79$ & Tinggi/kuat \\
$0,80-1,00$ & Sangat tinggi/sangat kuat \\
\hline
\end{tabular}

Sumber : Martono (2010)

Martono (2010) mengungkapkan pula, dalam menguji signifikansi KPM selain menggunakan nilai kritis KPM dengan Degree Of Freedom (df) $\alpha=0,05$, juga dapat menggunakan uji t dengan rumus:

$$
t_{\text {hitung }}=\frac{r \sqrt{n-2}}{\sqrt{1-r^{2}}}
$$


dengan derajat kebebasan atau $d \mathrm{k}=\mathrm{n}-2$, nilai t hitung dapat dibandingkan dengan nilai $t$ tabel dengan ketentuan, apabila $t$ hitung $\geq t$ tabel, maka $r_{X Y}$ adalah signifikan dan apabila $\mathrm{t}$ hitung $<\mathrm{t}$ tabel, maka $\mathrm{r}_{\mathrm{XY}}$ adalah tidak signifikan. Setelah nilai koefisien korelasi diperoleh, dihitung besarnya kontribusi atau koefisien determinasi variabel $\mathrm{X}$ dalam mempengaruhi variabel $\mathrm{Y}$, dengan menggunakan rumus $\mathrm{KP}=\mathrm{r}^{2} \mathrm{x} 100 \%$.

Pengujian asosiatif atau uji hubungan antara persentase tingkat kemiskinan dengan anggaran program pengentasan kemiskinan, dalam penelitian ini menggunakan data realisasi anggaran pemerintah selama kurun waktu 6 tahun terakhir (2013-2018) yang terdapat dalam dokumen Laporan Keterangan Pertanggungjawaban Akhir Masa Jabatan (LKPJ-AMJ) Walikota Pagar Alam Tahun 2013-2018 yang bersumber dari Sekretariat Daerah Kota Pagar Alam (2018). Alat bantu analisis korelasi dalam penelitian ini menggunakan perangkat lunak aplikasi IBM SPSS Ver 24.

\section{Analytical Hierarchy Process (AHP)}

AHP merupakan suatu metode pengambilan keputusan terhadap persoalan penentuan prioritas pilihan dari berbagai alternatif yang dapat membantu kerangka berfikir manusia. Metode AHP ini dikembangkan oleh Thomas L. Saaty pada awal tahun 1970-an. Proses hierarki analitik yang diuraikan Saaty memberikan kerangka yang memungkinkan untuk mengambil keputusan yang efektif atas persoalan rumit dengan jalan menyederhanakan dan mempercepat proses pengambilan keputusan yang dialami. Saaty (1993) menjelaskan pada dasarnya metode AHP ini memecah-mecah suatu situasi yang kompleks, tak terstruktur kedalam bagian-bagian komponennya, menata bagian atau variabel dalam suatu susunan hierarki, memberi nilai numberik pada pertimbangan subyektif tentang relatif pentingnya setiap variabel mana yang memiliki prioritas paling tinggi dan bertindak untuk mempengaruhi hasil pada situasi tersebut. Ilustrasi struktur hierarki keputusan digambarkan sebagai berikut:

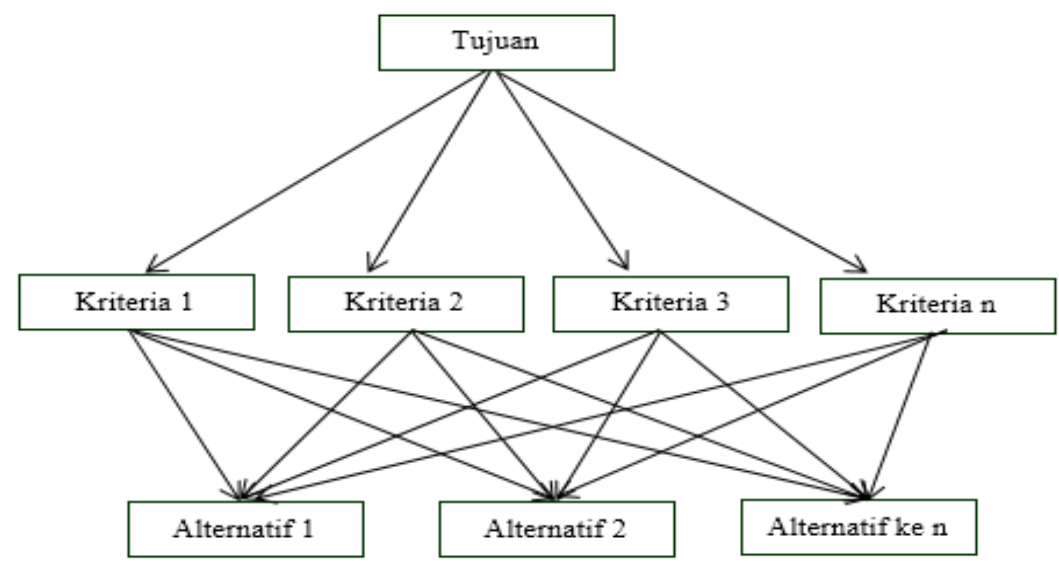

Sumber: diadaptasi dari Saaty (1993)

Gambar 1. Struktur Hirarki AHP

Adapun tahapan pelaksanaan metode AHP yang dikemukakan oleh Saaty (1993) antara lain:

1). Mendefinisikan persoalan dan merici pemecahan yang diinginkan;

2). Membuat struktur hirarki yang menyeluruh,;

3). Membuat matrik perbandingan berpasangan; 
4). Menentukan pertimbangan yang diperlukan untuk mengembangkan perangkat matriks dalam perbandingan berpasangan (skala banding secara berpasangan);

5). Memasukan nilai-nilai kebalikannya (reciprocal), mencari prioritas dan menguji konsistensinya;

6). Mengulangi langkah 3, 4, 5, untuk seluruh tingkat hirarki,

7). Menghitung vektor prioritas dari setiap matriks perbandingan, dan

8). Memeriksa atau mengevaluasi konsistensi seluruh hirarki, dengan mengalikan setiap indeks konsistensi dengan prioritas kriteria bersangkutan dan menjumlahkan hasilnya. (jika tidak memenuhi dengan $\mathrm{CR}<0,100$, maka penilaian harus diulang kembali).

Untuk memproyeksikan suatu hasil, metode AHP terlebih dahulu menilai atau membandingkan elemen mana yang lebih mungkin bersifat menentukan atau berakibat pada hasil yang terbentuk dari skala banding berpasangan. Pada Tabel 3, skala banding mendefinisikan dan menjelaskan nilai 1 sampai dengan 9 yang ditetapkan bagi pertimbangan dalam membandingkan pasangan elemen yang sejenis disetiap tingkat hierarki terhadap suatu kriteria yang berada setingkat di atasnya.

Tabel 3. Skala Banding Secara Berpasangan

\begin{tabular}{|c|c|c|}
\hline $\begin{array}{l}\text { Intensitas } \\
\text { pentingnya }\end{array}$ & Definisi & Penjelasan \\
\hline 1 & Kedua elemen sama pentingnya & $\begin{array}{l}\text { Dua elemen menyumbangnya sama } \\
\text { besar pada sifat itu }\end{array}$ \\
\hline 3 & $\begin{array}{l}\text { Elemen yang satu sedikit lebih penting } \\
\text { ketimbang yang lainnya }\end{array}$ & $\begin{array}{l}\text { Pengalaman dan pertimbangan sedikit } \\
\text { menyokong satu elemen atas yang } \\
\text { lainnya }\end{array}$ \\
\hline 5 & $\begin{array}{l}\text { Elemen yang satu esensial atau sangat } \\
\text { penting ketimbang elemen yang lainnya }\end{array}$ & $\begin{array}{l}\text { Pengalaman dan pertimbangan dengan } \\
\text { kuat menyokong satu elemen atas } \\
\text { elemen yang lainnya }\end{array}$ \\
\hline 7 & $\begin{array}{l}\text { Satu elemen jelas lebih penting dari } \\
\text { elemen lainnya }\end{array}$ & $\begin{array}{l}\text { Satu elemen dengan kuat disokong, dan } \\
\text { dominannya telah terlihat dalam praktik }\end{array}$ \\
\hline 9 & $\begin{array}{l}\text { Satu elemen mutlak lebih penting } \\
\text { ketimbang elemen lainnya }\end{array}$ & $\begin{array}{l}\text { Bukti yang menyokong elemen yang satu } \\
\text { atas yang lain memiliki tingkat } \\
\text { penegasan tinggi yang mungkin } \\
\text { menguatkan }\end{array}$ \\
\hline $2,4,6,8$ & $\begin{array}{l}\text { Nilai-nilai antara diantara dua } \\
\text { pertimbangan yang berdekatan }\end{array}$ & $\begin{array}{l}\text { Kompromi diperlukan antara dua } \\
\text { pertimbangan }\end{array}$ \\
\hline $\begin{array}{l}\text { Kebalikan } \\
\text { /Reciprocal }\end{array}$ & $\begin{array}{l}\text { Jika untuk aktivitas } i \text { mendapat satu } \\
\text { angka bila dibandingkan dengan } \\
\text { aktivitas } j \text {, maka } j \text { mempunyai nilai } \\
\text { kenalikannya bila dibandingkan dengan } \\
\text { elemen } i \text {. }\end{array}$ & \\
\hline
\end{tabular}

Sumber: Saaty, 1993

Dalam penentuan pengambilan keputusan, konsep AHP ditentukan oleh pendapat para ahli dalam Focus Group Discussion $(F G D)$ atau wawancara. Para ahli dianggap sebagai sumber terpercaya atas teknik maupun keahlian tertentu yang bakatnya untuk menilai dan memutuskan sesuatu dengan benar sesuai dengan bidang keahliannya. Penelitian ini pendapat para ahli atau responden berkaitan program prioritas penganggulangan kemiskinan di Kota Pagar Alam ditentukan secara sengaja (purposive) dengan pertimbangan responden paham dan sekaligus merupakan bagian dalam perumusan dan penentuan kebijakan programprogram pengentasan kemiskinan, sehingga memungkinkan pembobotan skala pembanding 
secara berpasang dalam AHP mempunyai nilai obyektivitas yang tinggi. Adapun responden yang diwawancarai pada penelitian ini sebagai berikut:

Tabel 4. Responden AHP

\begin{tabular}{clc}
\hline No & \multicolumn{1}{c}{ Responden } & Jumlah \\
\hline 1 & Wakil Walikota Pagar Alam (Ketua TKPKD) & 1 \\
2 & Sekretaris Daerah Kota Pagar Alam & 1 \\
3 & Kepala BAPPEDA Kota Pagar Alam & 1 \\
4 & Kepala Badan Keuangan Daerah Kota Pagar Alam & 1 \\
5 & Kepala Bagian Ekonomi dan Pembangunan & 1 \\
6 & Kepala Dinas Sosial Kota Pagar Alam & 1 \\
7 & Pejabat fungsional perencana BAPPEDA Kota Pagar Alam & 3 \\
8 & Akademisi (Dosen STIE Lembah Dempo Kota Pagar Alam) & 1 \\
& $\quad$ Total & 10 \\
\hline
\end{tabular}

Untuk mendapatkan total ranking alternatif program prioritas secara keseluruhan dalam model AHP didasarkan pada bobot nilai kriteria. Kriteria sasaran $S D G s$ dalam penelitian ini menggunakan indikator sasaran yang terdapat dalam ringkasan metadata indikator $S D G S$ yang ditetapkan oleh kementerian PPN/Bappenas (2017). Pilihan alternatif program prioritas terkait dengan target $S D G S$ ini menggunakan program-program utama pengentasan kemiskinan yang terdapat dalam Rencana Pembangunan Jangka Menengah Daerah (RPJMD) Kota Pagar Alam 2018-2023, yang bersumber dari Bappeda Kota Pagar Alam (2018). Alat bantu analisis AHP dalam penelitian ini menggunakan aplikasi perangkat lunak Expert Choice 11 .

\section{HASIL DAN PEMBAHASAN}

\section{Analisis hubungan anggaran program pengentasan kemiskinan}

Dari hasil pengujian korelasi dalam penelitian ini, dapat dijelaskan bahwa hubungan antara variabel persentase tingkat kemiskinan terhadap variabel anggaran program pengentasan kemiskinan di Kota Pagar Alam, berkorelasi signifikan apabila anggaran terhadap program-program kemiskinan tersebut tidak hanya bersumber dari APBD Kota Pagar Alam, melainkan didorong pula dengan program pengentasan kemiskinan yang bersumber dari APBN. Berdasarkan hasil output nilai pengujian antara persentase penduduk miskin dengan total anggaran keseluruhan (APBD Kota Pagar Alam ditambah APBN) memiliki nilai 0,033 atau lebih kecil dari prasyarat nilai yang telah ditentukan, yaitu kurang dari 0,05. Output pearson correlation yang senilai $-0,783$ dapat dimaknai pula, tingkat hubungan antara persentase kemiskinan dengan total keseluruhan anggaran program dikategorikan tinggi atau kuat. Nilai minus yang ditunjukkan dari hasil output pengolahan data menunjukkan pola arah hubungan yang mempunyai slope negatif, sehingga dapat dimaknai bahwa dengan meningkatnya anggaran program kemiskinan maka akan menurunkan persentase penduduk miskin. Untuk lebih lengkapnya hasil output pengujian korelasi disajikan pada Gambar 2.

Pencapaian program penanggulangan kemiskinan di Kota Pagar Alam, tidak terlepas dari kondisi atau kemampuan keuangan pemerintah daerah. Anggaran pendapatan dan belanja pemerintah tetap menjadi ujung tombak dalam menentukan berhasil tidaknya memberantas kemiskinan. Fahlevi dan Ananta (2015) menjelaskan bahwa kemampuan untuk merealisasikan anggaran (spending performance) menjadi sangat penting karena programprogram pemerintah berjalan atau tidak dapat dilihat dari kucuran dana APBD yang dianggarkan. Artinya, semakin rendah realisasi anggaran, maka semakin sedikit pula program dan aktivitas pemerintah yang dijalankan. Akhirnya, tujuan pemerintah tidak tercapai sesuai dengan harapan. 


\begin{tabular}{|c|c|c|c|c|c|c|c|c|c|}
\hline \multicolumn{10}{|c|}{ Correlations } \\
\hline & & Y & $\mathrm{X} 1$ & $\mathrm{X} 2$ & $\mathrm{X} 3$ & $\mathrm{X} 4$ & $\mathrm{Z}$ & $\mathrm{Z} 1$ & $\mathrm{Z} 2$ \\
\hline \multirow[t]{3}{*}{ Y } & Pearson Correlation & 1 & 223 &,- 407 &,- 248 &,- 114 &,- 234 &,- 390 &,$- 783^{\star}$ \\
\hline & Sig. (1-tailed) & & ,335 & ,212 & ,318 & ,415 & ,328 & ,222 & ,033 \\
\hline & $\mathrm{N}$ & 6 & 6 & 6 & 6 & 6 & 6 & 6 & 6 \\
\hline & $\begin{array}{l}\text { relation is significan } \\
\text { rrelation is significa }\end{array}$ & $\begin{array}{l}\text { vel }( \\
\text { evel }\end{array}$ & $\begin{array}{l}1 \text {-taile } \\
\text { (1-tail }\end{array}$ & & & & & & \\
\hline
\end{tabular}

Keterangan:

$\mathrm{Y} \quad=$ Persentase tingkat kemiskinan

$\mathrm{X}_{1} \quad=$ Program Pemberdayaan Fakir Miskin, KAT dan PMKS Lainnya

$\mathrm{X}_{2} \quad=$ Program Pelayanan dan Rehabilitasi Kesejahteraan Sosial

$\mathrm{X}_{3} \quad=$ Program Pemberdayaan Kelembagaan Kesejahteraan Sosial

$\mathrm{X}_{4} \quad=$ Program Pelayanan Kesehatan Penduduk Miskin

$\mathrm{Z} \quad=$ Total Anggaran Program Kemiskinan dari APBD Kota Pagar Alam

$\mathrm{Z}_{1} \quad$ = Program Keluarga Harapan (APBN)

$Z_{2} \quad=$ Total Anggaran Program Kemiskinan dari APBD Kota Pagar Alam dan APBN

Sumber : olahan penulis (2020)

Gambar 2. Output Pengujian Korelasi

Analisis AHP penentuan program prioritas pengentasan kemiskinan dengan pengarusutamaan pencapaian target SDGs

\section{Nilai bobot kriteria}

Berdasarkan perhitungan kumulatif dari responden atau para ahli dalam pertimbanganya menentukan kriteria indikator sasaran $S D G s$, yang menjadi prioritas utama adalah indikator sasaran Pengeluaran untuk layanan pokok (pendidikan, kesehatan dan perlindungan sosial) sebagai persentase dari total belanja pemerintah. Kriteria indikator sasaran ini dipilih menjadi sasaran yang lebih relevan dan representatif dengan nilai 0,369 lebih tinggi dibandingkan dengan kriteria indikator sasaran $S D G S$ yang lainnya. Nilai Inconsistency sebesar 0,00103 dapat dimaknai bahwa pilihan para ahli secara kumulatif di tingkat kriteria dikategorikan konsisten $(C R<0,1)$. Output nilai kriteria dalam model perhitungan model AHP menggunakan aplikasi Expert choice 11 dapat dilihat pada Gambar 3.

Sasaran SDGS Pengeluaran untuk layanan pokok (pendidikan, kesehatan dan perlindungan sosial) sebagai persentase dari total belanja pemerintah, yang terpilih menjadi prioritas sasaran utama, adalah sasaran paling objektif yang dapat dilakukan oleh pemerintah Kota Pagar Alam. Intervensi anggaran pemerintah Kota Pagar Alam dalam pengentasan kemiskinan akan lebih maksimal diarahkan pada, mengurangi beban pengeluaran masyarakat miskin dan mengoptimalkan fungsi pelayanan dasar pemerintah terhadap kelompok masyarakat yang kurang beruntung. Persepsi ini sesuai dengan hasil penelitian Gunamantha dan Susila (2015) yang mengungkapkan kemiskinan terjadi bukan semata-mata karena kurangnya pendapatan, tetapi karena tidak terpenuhinya hak-hak dasar masyarakat miskin untuk mempertahankan dan memenuhi kehidupan yang bermartabat sebagai bagian dari hak manusia yang paling asasi. 


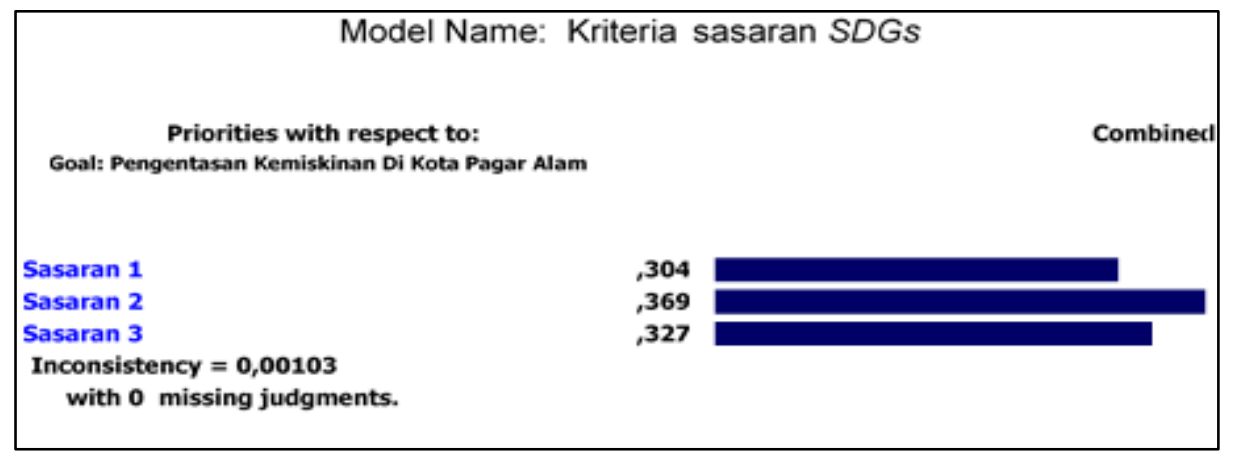

Keterangan:

Sasaran 1: $\quad$ Proporsi sumber daya yang dialokasikan oleh pemerintah secara langsung untuk program pemberantasan kemiskinan;

Sasaran 2: $\quad$ Pengeluaran untuk layanan pokok (pendidikan, kesehatan dan perlindungan sosial) sebagai persentase dari total belanja pemerintah;

Sasaran 3: $\quad$ Proporsi pengeluaran rutin dan pembangunan sektor-sektor yang memberi manfaat pada kelompok perempuan, kelompok miskin dan rentan;

Sumber: olahan penulis (2020)

\section{Gambar 3. Output Nilai Kriteria Berdasarkan Tujuan dalam Model AHP}

\section{Nilai Bobot Alternatif Program Prioritas}

Hasil penilaian para ahli terhadap alternatif program dengan kriteria indikator sasaransasaran $S D G S$, menunjukan Program Pelayanan dan Rehabilitasi Kesejahteraan Sosial dengan nilai bobot sebesar 0,351 menjadi prioritas utama dibandingkan dengan alternatif pilihan program yang lainnya. Struktur kombinasi keseluruhan penilaian para ahli dalam menentukan alternatif program prioritas utama atau yang lebih penting dan representatif terkait dengan kriteria seluruh indikator sasaran $S D G S$, memiliki nilai Overall Inconsistency sebesar 0,01 yang dapat diartikan bahwa perhitungan keseluruhan dari pendapat para ahli tersebut konsisten. Consistency Ratio dalam model AHP secara keseluruhan kurang dari 10 persen $(C R<0,1)$, dimaknai pula bahwa ketidakkonsistenan pendapat dari para ahli dapat diterima. Bobot prioritas alternatif program-program terkait dengan kriteria indikator sasaran $S D G s$ lebih lengakapnya tersaji dalam Gambar 4. Sedangkan, untuk susunan urutan peringkat program prioritas terdapat pada Tabel 5.

Program Pelayanan dan Rehabilitasi Kesejahteraan Sosial yang salah satu kegiatanya memberikan Bantuan Pangan Non Tunai (BPNT), seperti beras, telur, tempe dan kebutuhan pangan lainnya secara berkala kepada Keluarga Penerima Manfaat (KPM). Adalah suatu bentuk upaya nyata secara langsung untuk menghindari terjadinya kerawanan pangan masyarakat miskin. Dengan memenuhi kebutuhan makanan, diharapkan masyarakat miskin terhindar dari melakukan food coping yang cenderung memiliki efek negatif menurunkan gizi dan erat pula kaitanya dengan permasalahan kesehatan. Seperti halnya diungkapkan Anggrayni et al (2015) dan Syafani et al (2019) yang menyatakan bahwa pada tahap awal terjadinya kerawanan pangan, individu atau rumah tangga akan melakukan coping strategy berupa peralihan makanan dari makanan yang disukai menjadi makanan yang kurang disukai dan pada tahap lebih tinggi adalah mengumpulkan makanan liar atau dedaunan yang memungkinkan kurang bergizi. Tidak sedikit kritik terhadap program pemerintah yang memiliki sifat atau karakteristik berbasis charity ini. Program dengan mengedepankan sifat amal secara langsung dianggap program populer yang disukai masyarakat, akan tetapi tidak menyentuh akar permasalah kemiskinan. Namun yang patut dikedepankan ialah 
memposisikan masyarakat miskin ini kedalam darurat penanganan, dimana atas ketidakberdayaannya penduduk miskin tidak memiliki tenggat waktu untuk bertahan hidup lebih lama dibandingkan kategori penduduk lain, yang artinya program pemberian bantuan langsung memang sangat diperlukan. Di samping itu terkait tujuan SDGs yang ke-2 dan ke-3 yaitu tanpa kelaparan serta hidup sehat dan sejahtera, program proritas ini akan memiliki keterhubungan antar pencapaian target SDGS lainnya dan membawa implikasi bahwa kebijakan diambil berdasarkan daya ungkit yang tinggi ke tujuan dan target di luar ruang linkupnya sendiri.

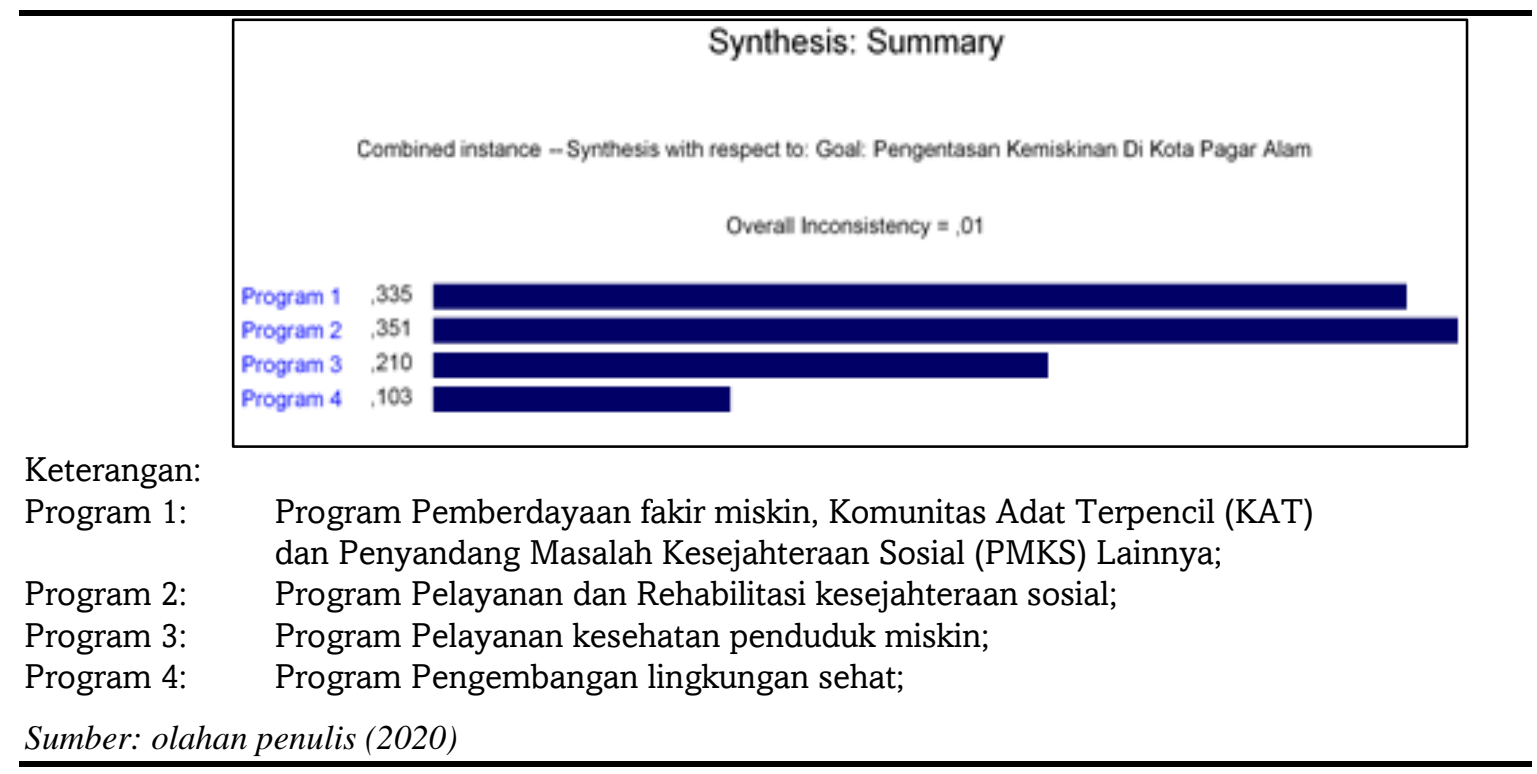

Gambar 4. Output Nilai Alternatif Berdasarkan Tujuan dalam Model AHP

Berkaitan dengan alternatif pilihan program pengentasan kemiskinan yang lain, yaitu pada Program Pelayanan Kesehatan Penduduk Miskin dan Program Pengembangan Lingkungan Sehat yang memiliki bobot masing-masing sebesar 20,9 dan 10,2. Kedua program tersebut tidak menjadi prioiritas penilaian dalam hal ini bukanlah kedua program tersebut tidak menjadi alternatif dalam pengentasan kemiskinan di Kota Pagar Alam, melainkan program tersebut belum saatnya untuk diprioritaskan pada periode saat ini, sebab dampak yang ditimbulkan pada sektor kesehatan akan terlihat dalam jangka waktu yang panjang. Hal ini sesuai dengan penelitian Sukarman, et al (2016) bahwa pengeluaran pemerintah di sektor kesehatan tidak secara langsung mengurangi jumlah kemiskinan, masih memerlukan jeda waktu agar tingkat kesehatan dapat mendorong masyarakat lebih mempunyai peluang untuk melakukan aktivitas ekonomi yang produktif untuk meningkatkan pandapatannya agar terlepas dari kemiskinan.

Tabel 5. Peringkat Alternatif Program Prioritas

\begin{tabular}{clc}
\hline Peringkat prioritas & \multicolumn{1}{c}{ Alternatif pilihan program } & Nilai bobot (\%) \\
\hline 1 & Program Pelayanan dan Rehabilitasi Kesejahteraan Sosial & 34,9 \\
2 & $\begin{array}{l}\text { Program Pemberdayaan fakir miskin, Komunitas Adat } \\
\text { Terpencil (KAT) dan Penyandang Masalah Kesejahteraan }\end{array}$ & 34,0 \\
& Sosial (PMKS) Lainnya & 20,9 \\
3 & Program Pelayanan kesehatan penduduk miskin & 10,2 \\
\hline & Program Pengembangan lingkungan sehat & 100 \\
\hline
\end{tabular}

Sumber: Analisis Peneliti, 2020 


\section{Alternatif Rekomendasi Penelitian}

Penyeragaman pengambilan kebijakan tanpa adanya identifikasi pola kemiskinan spasial akan memberikan dampak negatif pada tujuan penanggulangan tingkat kemiskinan Hasibuan et al (2019). Sukanto et al (2019) aspek spasial tidak dapat diabaikan dalam pembangunan daerah khususnya pengentasan kemiskinan. Pengentasan kemiskinan berbasis wilayah dapat dijadikan dasar dalam menentukan atau menetapkan kebijakan program agar dapat lebih tepat sasaran. Untuk itu, terkait dengan alternatif rekomendasi penelitian ini, strategi dalam mengimplementasikan program prioritas pengentasan kemiskinan berdasarkan kriteria sasaran $S D G s$ di Kota Pagar Alam dapat ditinjau dari persebaran rumah tangga miskin berdasarkan tingkat kesejateraan terendah di Kota Pagar Alam (Gambar 5).

Alternatif program prioritas pertama yaitu Program Pelayanan dan Rehabilitasi Kesejahteraan Sosial akan lebih optimal disasarkan pada rumah tangga miskin yang berada di Kecamatan Dempo Selatan. Kecamatan ini apabila ditinjau dari persebaran rumah tangga miskin jumlahnya memang relatif lebih sedikit dibandingkan dengan kecamatan lain, yakni kurang dari 15 persen dari total rumah tangga miskin yang ada di Kota Pagar Alam. Namun ditelaah dari struktur ruangnya kondisi di kecamatan ini minim akan infrastruktur konektivitas jaringan prasarana jalan, apabila kondisi ini terus berlangsung akan menyebabkan semakin beratnya beban yang ditanggung oleh masyarakat miskin untuk menggapai aksesabilitas terhadap kegiatan perekonomian mereka. Peningkatan akses terhadap pelayanan pendidikan, kesehatan, air bersih dan sanitasi, serta pangan dan gizi adalah kegiatan utama yang harus dilakukan oleh Pemerintah Kota Pagar Alam di Kecamatan Dempo Selatan. Harapanya dengan intervensi pemerintah ini akan mengurangi beban kelompok rumah tangga miskin, sehingga mereka yang tidak miskin agar tidak masuk menjadi kelompok miskin, dan mereka yang sudah miskin agar tidak menjadi lebih miskin, dengan kata lain terjadinya transformasi yang lebih baik dalam kelompok atau desil kesejahteraan penduduk.

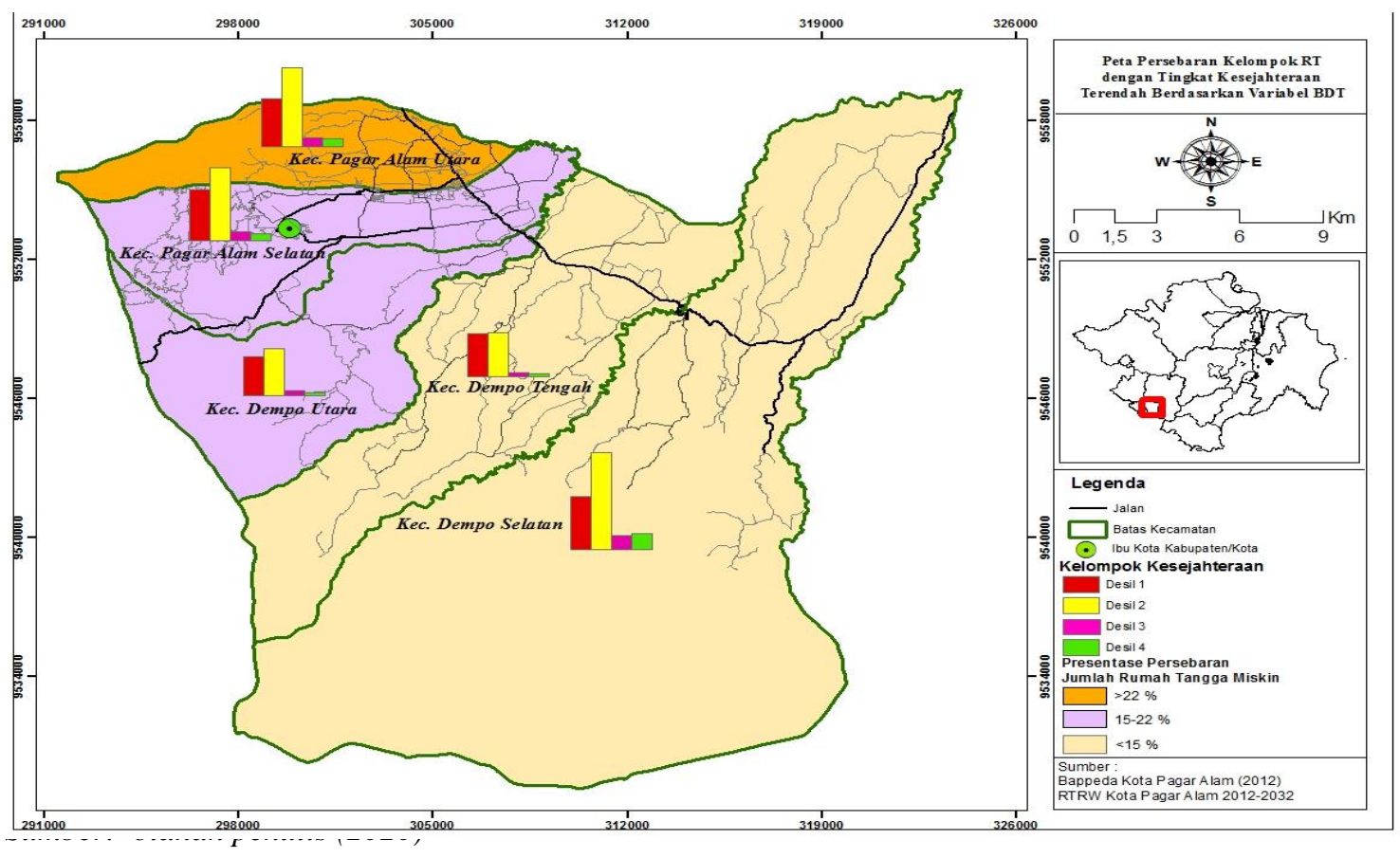

Gambar 5. Peta Persebaran Kelompok Penduduk Rumah Tangga dengan Tingkat Kesejahteraan Terendah 
Alternatif program prioritas kedua yaitu Program Pemberdayaan fakir miskin, Komunitas Adat Terpencil (KAT) dan Penyandang Masalah Kesejahteraan Sosial (PMKS) Lainnya, selayaknya diarahakan kepada rumah tangga miskin yang terdapat di wilayah Kecamatan Pagar Alam Utara dan Pagar Alam Selatan. Adanya pusat perdagangan dan jasa serta pusat pelayanan publik yang berada di kedua wilayah kecamatan tersebut menjadikan suatu keunggulan komparatif, dimana wilayah tersebut merupakan bagian wilayah perkotaan yang strategis. Selain itu, rentang kendali pusat pemerintahan yang berada di Kecamatan Pagar Alam Selatan, dapat memudahkan stakeholders terkait, untuk memantau perkembangan program pemberdayaan ini. Peningkatan keterampilan teknis dan akses permodalan kepada rumah tangga miskin adalah arahan kegiatan yang dapat ditempuh Pemerintah Kota Pagar Alam untuk menanggulangi kemiskinan, harapanya adalah ketika produktivitas rumah tangga miskin di kedua kecamatan ini berhasil diberdayakan dapat menyebar ke wilayah lain seperti pada Kecamatan Dempo Utara dan Dempo Tengah yang letak geografisnya cukup berdekatan, sehingga proses spread effect dalam mengentaskan kemiskinan di seluruh wilayah Kota Pagar Alam dapat diwujudkan.

Menurut Harmes et al (2017) suatu wilayah miskin cenderung mengikuti kondisi wilayah tetangganya, sehingga wilayah yang kemiskinannya rendah namun dikelilingi oleh wilayah yang kemiskinannya tinggi harus menjadi pusat perhatian agar jangan terjatuh dalam kondisi seperti tetangganya. Hasil penelitiannya menungkapkan, terdapat ketergantungan spasial pada data kemiskinan di Kota Bengkulu yang menyebabkan terbentuknya cluster kemiskinan yang diferensiatif antara satu wilayah dan wilayah lainnya. Pendapat ini diperkuat oleh Hasibuan et al (2019) dan Sukamto et al (2019) yang menyebutkan adanya pengelompokan dan konsentrasi pola kemiskinan di Kabupaten Bandung Barat, serta adanya pola spasial positif dan berkelompok pada data kemiskinan di Kabupaten Pandeglang dan Kabupaten Lebak. Hasil studi di Kota Pagar Alam ini kemiskinan terkonsentrasi di pusat kota pada Kecamatan Pagar Alam Utara. Wilayah yang terdekat dari tingginya data kemiskinan tersebut yaitu di Kecamatan Pagar Alam Selatan dan Kecamatan Dempo Tengah yang letak geografisnya cukup dekat dengan kantong kemiskinan di Kota Pagar Alam.

Intervensi pemerintah dalam pengentasan kemiskinan harus dilihat berdasarkan pada wilayah di sekitarannya sehingga penetapan lokasi target program penanggulangan kemiskinan akan semakin nyata mengikuti kondisi yang ada di masing-masing wilayah. Oleh karena itu, program pengentasan kemiskinan tiap kecamatan harus disesuiaikan dengan masing-masing karakteristik wilayahnya. Perbedaan penelitian ini dengan penelitian sebelumnya adalah selain memetakan kemiskinan spasial, memberikan pula suatu langkah alternatif kebijakan strategis yang dapat di tempuh stakeholders terkait khususnya di Kota Pagar Alam dan secara umum dapat menjadi referensi pemerintah daerah lain dalam mengimplementasikan $S D G$ s tanpa kemiskinan di wilayahnya masing-masing.

\section{KESIMPULAN}

Berdasarkan hasil dan pembahasan penelitian, maka dapat disimpulkan bahwa kolaborasi penganggaran program pengentasan kemiskinan yang terpadu melalui APBD Kota Pagar Alam dikombinasikan dengan APBN memiliki pola hubungan signifikan dengan penurunan persentase tingkat kemiskinan. Program Pelayanan dan Rehabilitasi Kesejahteraan Sosial dalam model AHP merupakan program peringkat pertama atau pilihan utama dalam kerangka pengentasan kemiskinan dengan pengarusutamaan $S D G S$. Merujuk pada hasil statistik dalam pengujian korelasi pearson yang membuktikan anggaran program-program pengentasan kemiskinan secara parsial tidak menunjukan hubungan yang signifikan. Maka saran untuk ditindaklanjuti dari penelitian ini adalah alternatif program prioritas yang terpilih tidak dapat berdiri sendiri untuk mengentasakan kemiskinan. Program prioritas tersebut harus terus diupayakan didampingi oleh program-program lain yang berkaitan dengan kemiskinan. 
Selanjutnya terkait dengan aspek spasial yang tidak dapat dipisahkan dalam pengambilan keputusan atas kebijakan program anti kemiskinan. Pemerintah Kota Pagar Alam perlu memusatkan perhatian terhadap daerah dengan kantong kemiskinan terbesar ataupun terdekat dengan pusat pemerintahan, yang mencerminkan ada upaya yang nyata dalam mencapai target SDGs tanpa kemiskinan. Selain itu, Pemerintah Kota Pagar Alam perlu menyusun kerangka umum atau roadmap $S D G s$ tanpa kemiskinan yang baku. Upaya ini dimaksudkan agar dalam pelaksanaan $S D G s$ dapat konsisten sesuai dengan konteks yang ada, terlepas dari perubahan-perubahan kebijakan, pendanaan dan juga sumber daya manusia yang seringkali terjadi dalam keseharian pemerintah daerah.

\section{DAFTAR PUSTAKA}

Alisjahbana, A. S. dan Murninigtyas, E. (2018). Tujuan Pembangunan Berkelanjutan di Indonesia : Konsep, Target dan Strategi Implementasi. Unpad Press, Bandung. $319 \mathrm{hlm}$.

Amin, C. dan Musiyam, M. (2017). Pengantar Perencanaan Wilayah: Perspektif Geografi. Muhammadiyah University Press, Surakarta. $243 \mathrm{hlm}$.

Anggrayni, F. M., Andrias, D. R. dan Adrian, M. (2015). Ketahanan Pangan dan Coping Strategy Rumah Tangga Urban Farming Pertanian dan Perikanan Kota Surabaya. Media Gizi Indonesia, 10(2), 173-178. http://dx.doi.org/10.20473/mgi.v10i2.173-178.

Asra, A. (2014). Esensi Statistik Bagi Kebijkan Publik. Penerbit In Media, Bogor. $376 \mathrm{hlm}$.

Bappeda Kota Pagar Alam. (2018). Rencana Pembangunan Jangka Menengah Daerah (RPJMD) Kota Pagar Alam Tahun 2018-2023. Pemerintah Kota Pagar Alam, Pagar Alam.

Bappenas. (2017). Ringkasan Metadata Indikator Tujuan Pembangunan Berkelanjutan (TPB)/Sustainable Development Goals (SDGs) Indonesia. Kementerian PPN/Bappenas, Jakarta. $99 \mathrm{hlm}$.

Fahlevi, H. dan Ananta, M. R. (2015). Analisis Efisiensi dan Efektivias Anggaran Belanja Langsung - Studi pada SKPD di Pemerintah Kota Banda Aceh. Jurnal Ilmiah Administrasi Publik, 1(2), 37-44. https://doi.org/10.21776/ub.jiap.2015.001.02.6.

Gunamantha, I. M. dan Susila, G. P. A. J. (2015). Analisis Dampak Program Pengembangan Kecamatan Terhadap Pengentasan Kemiskinan di Kabupaten Buleleng. Jurnal Ilmu Sosial dan Humaniora, 4(1), 523-533. https://dx.doi.org/10.23887/jish-undiksha.v4i1,4921.

Hasibuan, S. N., Juanda, B. dan Mulatsih, S. (2019). Analisis Sebaran dan Faktor Penyebab Kemiskinan di Kabupaten Bandung Barat. Jurnal Agribisnis Indonesia (Journal of Indonesian Agribusiness), 7(2), 79-91. https://doi.org/10.29244/jai.2019.7.2.79-91.

Harmes, H., Juanda, B., Rustiadi, E. dan Barus, B. (2017). Pemetaan Efek Spasial pada Data Kemiskinan Kota Bengkulu. Jurnal Perencanaan Pembangunan Wilayah Dan Perdesaan (Journal of Regional and Rural Development Planning), 1(2), 192-201, https://doi.org/10.29244/jp2wd.2017.1.2.192-201.

INFID. (2016). Sustainable Development Goals-SDGs Panduan Untuk Pemerintah Daerah (Kota dan Kabupaten) dan Pemangku Kepentingan Daerah. International NGO Forum On Indonesian Development, Jakarta. 78 hlm.

Mahi, A.K. dan Trigunarso, S.I. (2017). Perencanaan Pembangunan Daerah Teori dan Aplikasi. Kencana, Depok. $300 \mathrm{hlm}$.

Martono, N. (2010). Statistik Sosial Teori dan Aplikasi Program SPSS. Gava Media, Yogyakarta. 304 hlm.

Saaty, T. L. (1993). Pengambilan Keputusan Bagi Para Pemimpin Proses Hirarki Analitik Untuk Pengambilan Keputusan Dalam Situasi Yang Kompleks. Cetakan kedua. PT Gramedia, Jakarta. $270 \mathrm{hlm}$.

Sekretariat Daerah Kota Pagar Alam. (2018). Laporan Keterangan Pertanggungjawaban Akhir Masa Jabatan (LKPJAMJ) Walikota Pagar Alam Tahun 2013-2018. Pemerintah Kota Pagar Alam, Pagar Alam.

Sukanto, S., Juanda, B., Fauzi, A. dan Mulatsih, S. 2019. Analisis Spasial Kemiskinan Dengan Pendekatan Geographically Weighted Regression: Studi Kasus Kabupaten Pandeglang dan Lebak. TATALOKA, 21(4), 669-677. https://doi.org/10.14710/tataloka.21.4.669-677.

Sukarman, R., Marwa, T. dan Husin, T. 2016. Analisis Pengaruh Belanja Pemerintah di Bidang Kesehatan, Pendidikan, dan Belanja Modal Terhadap Tingkat Kemisikinan di Provinsi Sumatera Selatan. Jurnal Pembangunan Manusia Balitbangda Provinsi Sumatera Selatan. 10(1), 61-78.

Syafani, T. S., Sayekti, W. D. dan Zakaria, W. A. 2019. Food Coping Strategy Rumah Tangga Sasaran Penerima Manfaat Beras Sejahtera di Kabupaten Pringsewu. Indonesian Journal of Socio Economics. 1(1), 61-71. 